\title{
III. 社会の変化と内科学・内科診療
}

\section{0. 環境問題と内科学一水俣病の経験から一}

\begin{tabular}{|c|c|}
\hline 倩此古 & 周峖 \\
\hline 一安 幸治 & 竹迫 \\
\hline
\end{tabular}

Key words: 水俣病, アルキル水銀中毒, 有機水銀中毒, 視野狭窄, 公害

\section{1. 水俣病の経験}

水俣は熊本市の南方約 100 籸, 鹿児島県との 県境に近い人口約 4 万の小都市である。水俣病 発生当時は, 熊本市とを結ぶ舗装道路は 1 本も なく, 専ら鉄道で 2 時間以上を要した。この小 都市にチッソ株式会社が君臨し，市長は元工場 長でありここの会社が町の死活を握っていたと 言っても過言ではない. 昭和 30 年頃は日本の産 業の興隆期で, この会社も煤煙を空高く吹き上 げて増産を謳歌していた。

この町に得体の知れない病気が次々と発生し, 地元の医師会, 保健所, 市民病院などが中心と なり「水俣奇病対策委員会」を作ったが対応し きれなくなり，31 年 8 月, 熊本大学医学部にそ の解明を依頼して来た。 そこで医学部長は学内 十余りの講座に協力を依頼し, 水俣病研究班を 作ってこの病気に对応することになった. 当時 私共の内科は勝木司馬之助教授が主任で, 私共

とくおみ はるひこ：熊本大学名誉教授

おかじま とおる：大分医科大学名誉教授

いえむらてつふみ，いちやすゆきはる，たかば

みつや,やました まさひろ:元 熊本大学第一内科
はその指導下にあったが，昭和 31 年 12 月，勝 木教授は九大に転出され，徳臣がその後の水俣 病研究の任に当ることになった。

1) 疫学的状況

患者が多発したのは水俣尓の奥座敷で, 袋湾 に面した南西部の 1 帯で, 患者の殆どが漁民と その家族であった，加えてその部落の飼猫がア チコチで奇妙は行動をとり，最後は狂い迴って 海に飛び込んだりして死亡していた。最初は脳 炎が疑われたが，調べてみると炎症所見は全く なく，漁民と猫を結ぶと中毒，しかも魚を介し ての中毒という線が濃厚になって来た。ここま ではスムーズに到達することが出来た。

2）臨床面よりの取り組み

未知の聅患を診断・解明するために, 我々臨 床に携る者として先ずやらなければならないこ とは, 患者の病状・所見を正確に把握して, そ のクライテリアを確立する以外にはないと考え た.ただ本病は多彩な神経症状を主徴とする疾 患である、神経学会の発足を遡ること 4 年のこ の時代において, 神経学的訓練をほとんど受け ていない我々は，一時ほとんど途方に暮れる思 いであった．しかしすべての患者の諸動作をフ イルムに納めることから始めようと考え，スイ 
ス製の撮影機ボレックスを十数万円で購入し， 16 ミリ富士フイルムで患者の一挙手, 一投足を 撮影した．幸いに教室に 2 人の玄人はだしの写 真マニアが居て, 本研究の大きな推進力となっ た.もう一つ，患者の特徴として，喋り方がす べて子供っぽくなっていることが気づかれた。 その言葉は，その当時の，一抱えもある大きな テープレコーダーを持ち込んで録音した.

この様にして，診ることの出来た患者のすべ ての病像を映し出し，言葉を録音することによっ て，1人，1 人を正確に記録し続けた. 現今と比 ベると, 1956 年時代はすべての点で未開の時代 であった.

\section{3）臨床的観察}

当時, 熊大病院は空襲で焼失し, 約 $2 \mathrm{~km}$ 離れ たトタン茸きの陸軍病院跡を借りて患者を収容 していた. 我々は毎日, 外来一病棟間のこの距 離を歩いて往復していた。ここに収容した水俣 病患者は 10 名余りで, その後は新しい患者発生 の報が届くと, 土曜・日曜を利用して, 鈍行で 2 時間あまりかけて水俣に着き, 患者宅に赴いて 診察し，撮影した．その頃の患家は多く海に面 した斜面にあり，電燈のない家も時に見受けら れた. 当時,水俣の魚は危ないという風評が立っ ていたので, 商売に差し支えるとして, 新患を なるべく外に出さない様にしていた。

\section{4) 天佑の本}

1957 年 3 月末から 4 月上旬にかけて内科学会 等出席のために上京した。その当時は特急で東 京までまる1日の長旅であった.

その一日，本郷から日本橋にかけて医学書店 を回り, 中毒の専門書を探し求めた. 中毒の専 門書は非常に少なく, 特に和書では皆無であっ た.わずかに英文の本 2 冊と独文の本 1 冊を見 出し, 買い求めた. 助教授の安い給料では高い 買い物であった，その頃は，教室の僅かな年間 費は研究用のみに当てられ，水俣往復はじめ， すべて出張費は自費で賄っていた.

このうちの 1 冊が水俣病解明に大きな原動力
となったもので，私にとって天佑というにふさ わしいものであった. その本はNIHのVon Oettingen著のPOISONINGである.この本は面白い 形式で書かれていた，その形式は，「頭痛」「めま い」といった症状をあげて，その下にその症状 を惹き起こす毒物名を列記してあった。 そこで 殆どの水俣病患者に認められた「視野狭窄」の 項を開いてみると alkyl mercuryがトップに挙げ られていた。また 'ataxia'の項をみると、ここ でもalkyl mercuryがトップに挙げられていた。 更にこの本の後半には, 簡単な解説がアルファ ベット順に並べられていた. alkyl mercuryの項 には視野狭窄, 運動失調, 難聴, 四肢の感覚障 害など，本病と似通ったことが書かれており， 次の文献が記載されていた。

Hunter D, Bomford RR and Russell DS : Quart J Med $9: 193,1940$.

私はこの文献を東大図書館から取り寄せて読 んで見たところ，水俣病とよく似ていたので， 工学部関係の人に, チッソではアルキル水銀を 使っていますかと訊ねて見た.「無機水銀は触媒 として使っていますが，有機はネー」という答 えであった。私は，あの広い海を污染し，生物 を殺傷する程の大量の高価な水銀を営利会社が 放出，放置する筈が無いと考え，水銀から離れ ていった。

\section{5） 2 年間の苦䦔}

それからの 2 年間, マスコミを中心に世論は， 「熊大は何をしているのか」,「駅弁大学に頼むか らこんなことになる」など，非難ごうごうとし て責め立てられた，しかし道は唯一筋，出来る だけ多くの患者に接しその寒態を確寒に掴むこ とと考え，水俣行きを絽り返したが，その数は 数十回に達したと思う.

2 年間の苦行の末, 詳細な観察の出来た患者が 34 例に達したので, その症状・所見を集計した ところ図1の如くになった.すなわち，視野狭 窄, 難聴, 言語障害, 運動失調, 感覚障害, 振 戦等は 70〜90\%にに達して，先に読んだHunter 


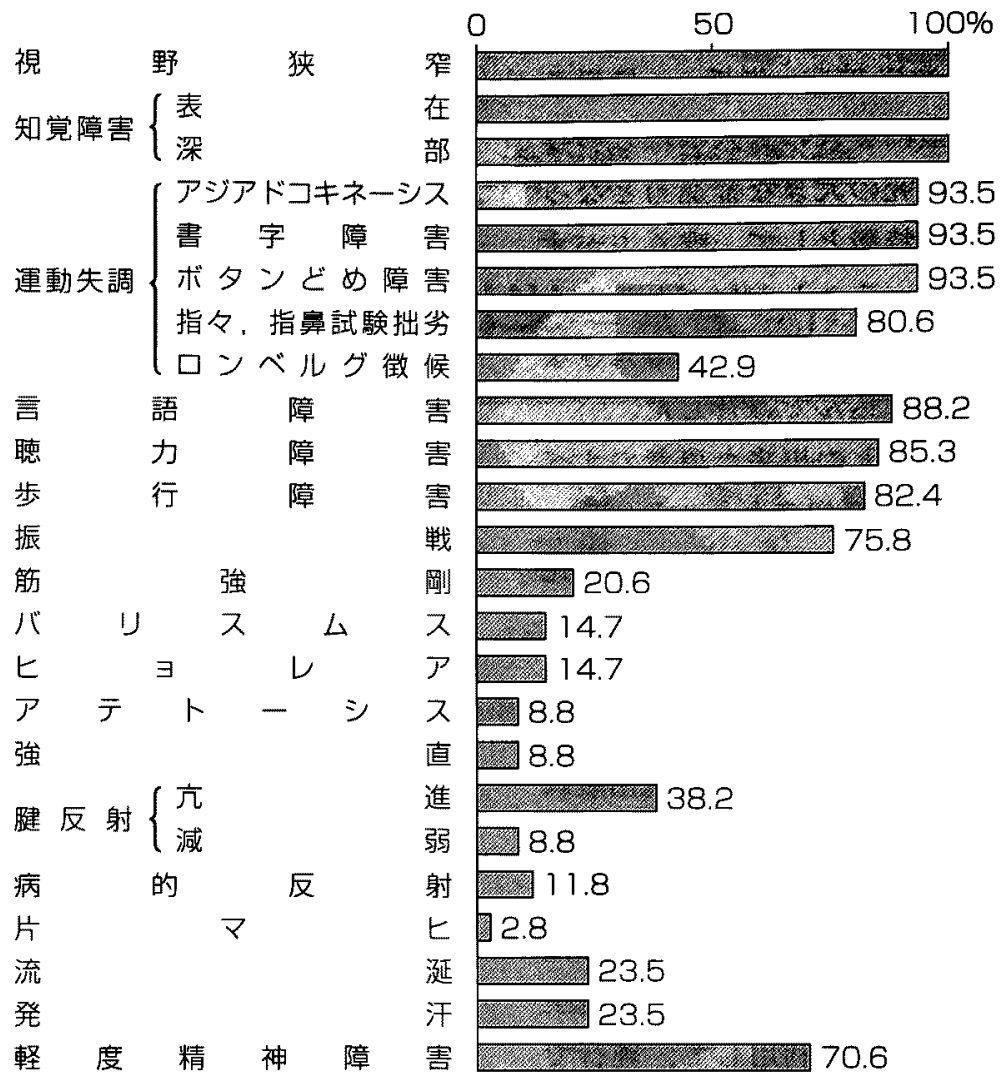

図 1. 症状発現頻度（34 例，1960 年）

らの論文にほぼ一致するものであった，更に入 念に観察した 34 例の経過より，

普通型 Common Form

急性劇症型 Acute Fulminant Form

慢性刺激型 Chronic Form with Irritation

慢性強直型 Chronic Form with Contracture の 4 型に分類したが，その詳細は省略する.

6）尿中水銀量

この様にして本病は臨床的に有機水銀中毒に 一致すると考えられたので，公衆衛生学教室の 喜田村教授にお願いして尿中水銀量を測定して いただいた. その結果, 健康人 11 名の尿中水銀 量は何れも $15 \gamma / l$ 以下であったのに対し, 水俣病 患者では 115〜134 $\gamma /$ dayであった. 更にキレート 剤であるBAL投与例では, 前值 45 $\gamma /$ dayであった のがBAL投与後 $190 \gamma /$ day と增加し, EDTA-Ca
投与でも同様の成績が認められ，有機水銀中毒 である可能性がより一層強くなった.

\section{7) 発病猫}

(a) 自然発病猫

もう一つ奇妙な事実は，先にも述べた猫の発 病であった。現地の人は「猫がもう（舞う)」と 言っていた. 飼猫の発病は患者発生の予兆と恐 れられていた。 その様な猫が居たら見せてくれ と頼んでいたら，一匹垷まったというので研究 室に持ち帰って動作を16ミリに記録した。

その猫を詳細に観察すると, 瘦せて, 毛が粗 になり，艶を失っていた，歩き方はヨロヨロし て酩酊状である．飭で誘って階段を降りさせる と足を踏み外して転んでしまった．持ち上げて 横にして落とすと, ヒラリと立つ筈の猫がその まま胴体着陸した。いつもダラダラと涎を垂ら 
している. その状態が 3〜4 日続いた後，突如ひ どい流涎で全身びしょびしょになり，やみくも に突進,逆立ちを繰り返して死亡してしまった。

(b)魚介類投与猫

水俣湾内の岩石に生育しているヒバリガイモ ドキ (通称黒貝) を採取し， $60 \sim 70^{\circ} \mathrm{C}$ でボイル し，天日に干して持ち帰り実験に供した，その 結果, 大体 $22 \sim 35$ 日徯に発病し, 自然発病猫上 全く同じ病状を辿り死亡した．投与量を半減す ると発病が 2.5 5 倍延長した.

(C)エチール燐酸水銀投与実験

有機水銀の一つであるエチル燐酸水銀が入手 できたので投与実験を行った. 1 日 1 4mg投与 で最短 9 日, 最長 32 日で, 貝投与の場合と同様 の結果が得られた.

\section{8）有機水銀中毒と結論}

臨床所見, 尿中水銀排泄增加, 猫実験の結果 などから，本病の原因は有機水銀中毒と確信し ているところへ, 脳の病理所見も有機水銀中毒 に一致するとの病理学教室武内教授からの知ら せがあり，また喜田村教授から，水俣湾内のへ ドロ，魚介類からも大量の水銀が証明されたと のことで, 我々の考え方が正しかったことが確 実になった.こうして熊本大学水俣病研究班が, 「魚介類を污染している毒物として, 水銀が極め て注目されるに至った」と公表したのは昭和 34 年 7 月のことであった。

\section{2. 水俣病の経験から環境問題への提言}

\section{1) 時代背景}

昭和 31 年（1956 年）頃は, 1950 年の朝鮮戦 争勃発を契機として，すべての産業が上向きに なり，戦後日本の復興の為には多少の犠牲も已 むを得ないという風潮があった。水俣病の多発 はその余波として起った出来事で, 工業界にも 国にも会社擁護の態度が明らかで, 我々の研究 に対しても，表面では協力的に見えながら，他 面では非協力的な部分が少なくなかった. 昭和
34 年に, 水俣病の原因は水銀ないし有機水銀で あると熊大研究班が発表し，内外の識者がすべ て承認していたのに，国がこれを認めたのは昭 和 43 年のことで,この間, 実に 9 年間も放置さ れていたわけである.また，新潟に第 2 の水俣 病が発生しなかったならば，熊本水俣病はメチ ル水銀中毒症として認定されなかったであろう とも言われている．公害の概念は，一般にはこ れほど低調であった。

医学の分野でも，中毒に関する専門の研究機 関は皆無であり，日本語の専門書は一冊も無く， 何を基準に研究を進めるべきか，どこにも拠り 所はなく，手探りの研究遂行であった.

\section{2）内科医としての態度}

現在のアフガニスタンの様な，原始的とも言 える当時の舞台の上で，考え，行ったことは， 「この奇病と言われているものも内科疾患の一つ である.それなら 1 人でも多くの患者について， 多種多様な所見を正確に捉え，公約数的クライ テリアを求めて，その本態を世界の文献に伝え ようではないか」と考え，それに向かって努力 を重ねたのである．昔から伝えられ，教えられ た内科診断学の本旨はこれではなかったかと思 う. 現代医学からみれば我々の辿った道は甲贯 をつけた「関ヶ原の戦い」の様に映るかもしれ ないが, 万余の機器に中に動いている現代医学 の中にも，この様な精神は生かし続けなければ ならないと考える．環境污染により，新しい形 の中毒が何時, 何処で, どの様にして, 起るか 判らないが,これらに最初に関わるのは通常内 科医であろうが，一人一人の患者を詳細に見定 める態度を忘れないで欲しいと考えている。

\section{3）公害被害者認定への対応}

水俣病問題が起るまでは，公害という概念は 日本では真剣に取り上げられることは無かった 様に思う. 或る企業が原因で不特定多数が災害 を蒙った場合は私害であり，不特定多数の企業 が釀し出す災害が公害であるという説を聞いた ことがあるが，何れにしても企業が原因である 
ことに変わりはない. 公害ということになれば 被害者への補償・救済がつき物であり，そのた めには認定という作業が必要になる. 我々は被 害者の認定に関わる業務に関しては，国が指定 した医師以外に，他の職業人，例えば法律家を 加えた専門の機関がその任にあたる事が望まし いと考えている．診断と認定業務は別種の事項 である。そこには純医学的観点以外に，社会的 考慮も加わることが多いからである．医師の眼 で診断に踏み切れないケースも，医師以外の眼
を加えて判断することになれば，トラブルも少 なくなるのではないかと考えるのである.

以上私共の行って来た研究が, 多少なりとも 寄与する処があれば幸いである。

\section{文献}

1）徳臣晴比古, 他：水俣病に関する研究，第 5 報. 臨床的 及び実験的研究より見た本病の原因について。熊本医会 誌，34（補 3）：490-510, 1960.

2) Tokuomi H, et al : Minamata disease. World Neurol $2: 536$ $-545,1961$. 